\title{
The impact of Greening Systems on building energy performance:
}

\section{A Literature Review}

\author{
Babak Raji $^{\text {a,* }}$, Martin J. Tenpierik ${ }^{\text {a }}$, Andy van den Dobbelsteen ${ }^{\text {a }}$ \\ a Delft University of Technology, Faculty of Architecture, P.O. Box 5043, 2600 GA Delft, The Netherlands \\ * Corresponding author. \\ Tel.: +31-619999508 \\ E-mail address: b.raji@ tudelft.nl (B.Raji).
}

\begin{abstract}
Scarcity of resources and environmental issues caused by human activities stimulate designers and policy makers to search for energy efficient strategies for sustainable development. A considerable amount of energy consumption and $\mathrm{CO}_{2}$ emission comes from the building sector which today accounts for $40 \%$ of the world's energy use. Greenery systems are considered as a promising solution for making buildings more energy efficient. However, energy saving is one among multiple benefits that a greenery system can offer to a building. The most common places in a building that can be used to accommodate vegetation include roof greening, vertical greening, terrace planting and sky gardens (indoor and outdoor) especially in the design of high-rises. Therefore, the main aim of this paper is to provide a literature review for all different greening systems with respect to their energy impact. The role of indoor planting on thermal comfort and indoor air quality (IAQ) will also be discussed. Furthermore, the suitability of different greenery systems for different climate types is summarized.
\end{abstract}

\section{Content}

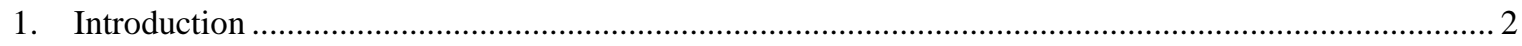

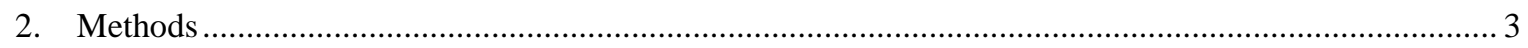

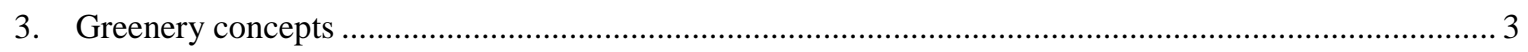

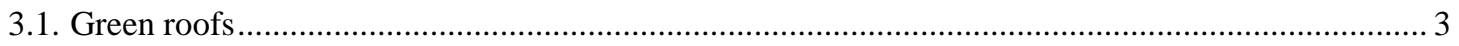

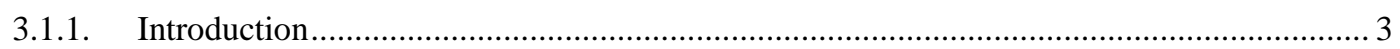

3.1.2. The impact of green roofs on temperature and heat flux .............................................. 4

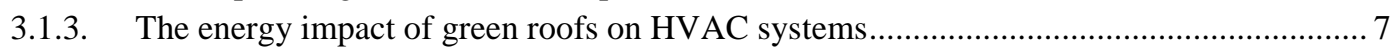

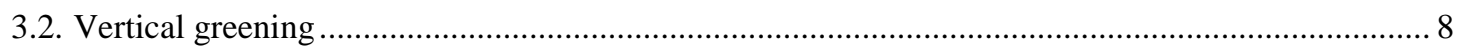

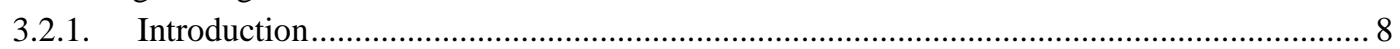

3.2.2. The impact of green walls on temperature and heat flux .............................................. 9

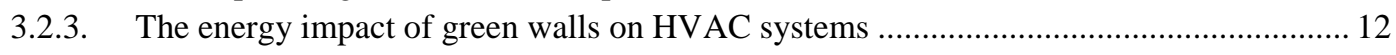

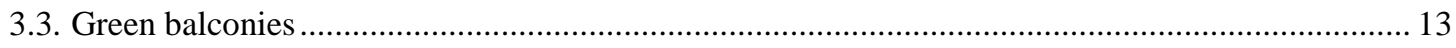

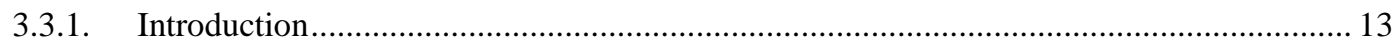

3.3.2. The impact of green balconies on temperature and heat flux.......................................... 13

3.3.3. The energy impact of green balconies (shading trees) on HVAC systems ......................... 14

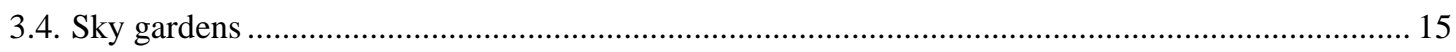

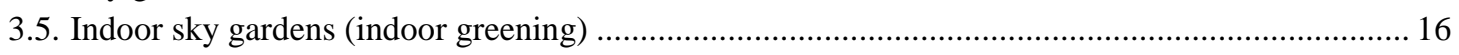

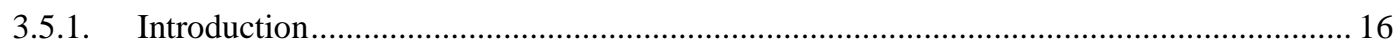

3.5.2. The impact of indoor planting on indoor air quality ...................................................... 16

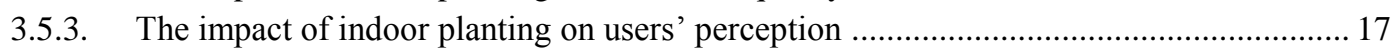

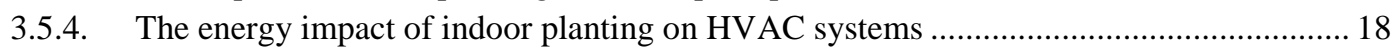

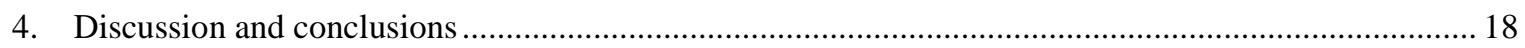

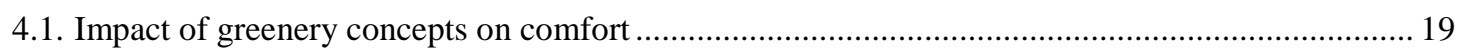

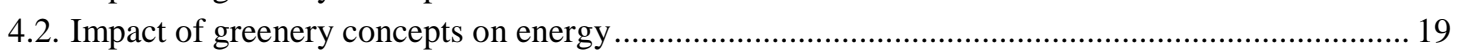

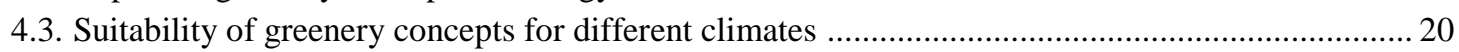

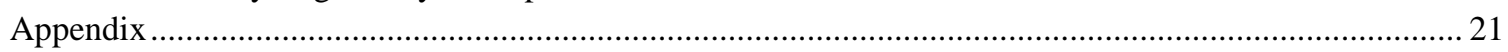

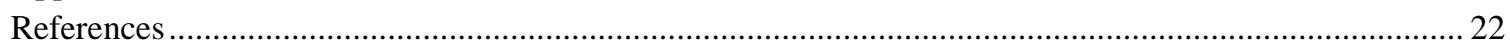




\section{Introduction}

For the first time in 2008, over half of the world population lived in cities. The United Nations estimates that by 2050, the urban population will reach a new peak of around $67 \%$ [1]. According to Wood [2], with the current rate of urbanization, a new city is needed to accommodate one million new urban inhabitants around the world every week. A big challenge for urban planners in the 21st century is accommodating these new urban inhabitants with adequate facilities.

Dense urban areas has been the source of environmental issues like urban heat island, depletion of resources and air and water pollutions. Therefore, designers and planners should take sustainability in the development of buildings into account. It means that in the future designs of our built environment should be climate-adaptive and rely on renewable and recyclable resources [3]. To adapt our built environment to the natural environment, Yeang suggests that "our constructions must imitate ecosystems in all aspects" (p. 412) [4].

Typically, dense urban areas are composed of a huge quantity of inorganic resources from distant places and assembled intensively in a small portion of land; therefore, they exert a dramatic pressure on the biosphere by changing the balance of organic and inorganic content. According to Yeang we must maintain a balance between biotic and abiotic through adding appropriate levels of biomass, improving biodiversity and making ecological connections in our built environment [4]. In line with Yeang, Wood [2] noted that if cities are seeking to accommodate a large group of people on the same area by building upward, then they require imitating the ground floor atmosphere up in the sky, including green spaces, sidewalks and other public functions.

The most common places in a building that can be used to accommodate vegetation are roof greening, vertical greening, terrace planting and using indoor plants in atria especially in the design of high-rises, as shown in Fig. 1. In recent years, much research has been done on the benefits of using greenery concepts with different objectives, scopes and methodologies. However, there has been more research done in some areas than in others. The main aim of this paper is to provide a literature review for all different greening systems with respect to energy impact.

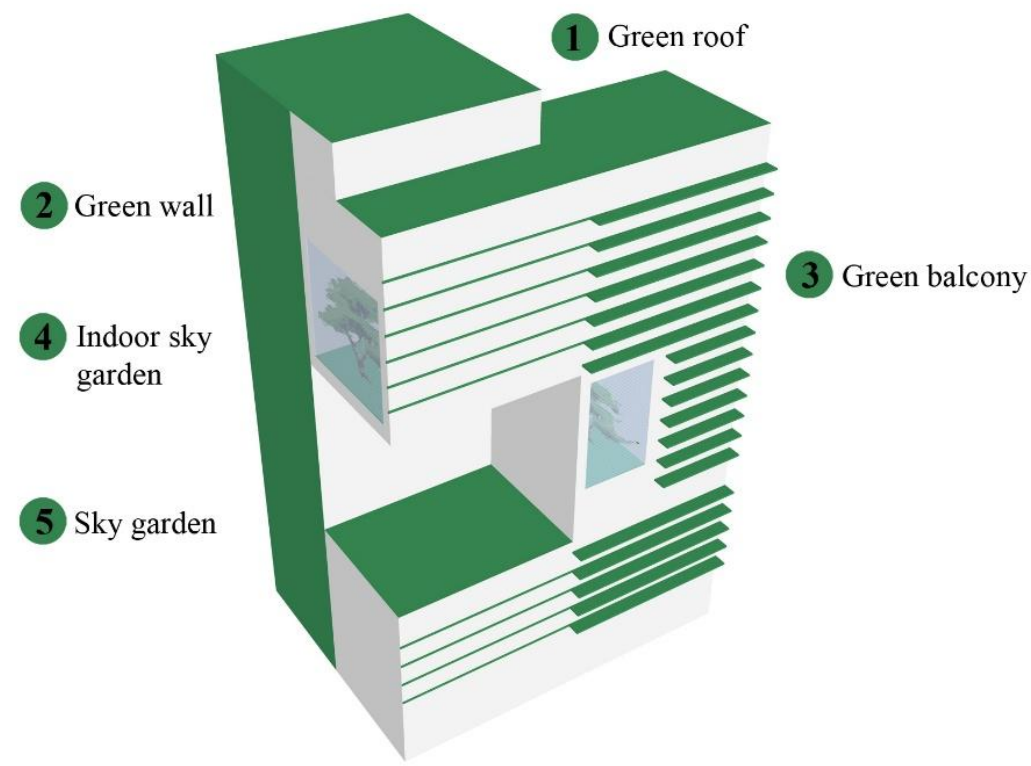

Fig. 1. Different ways of integrating greenery systems on buildings 


\section{Methods}

This paper presents literature concerning the application of greenery systems on our built environment, with a focus on energy related topics. The literature review looks at a time frame from 1977 through late 2013 and encompasses five greenery concepts including the green roof (GR), green wall (GW), green balcony (GB), sky garden (SG) and indoor sky garden (ISG). Each greenery concept is investigated in a separate section. Therefore, each section includes an overview on the history, definitions and different categories of that greenery concept followed by its potential benefits for a building. After a brief introduction, the thermal impact of each concept, besides its impact on building's energy consumption, will be studied. As there has been little research available on some areas like green balconies or sky gardens, the aim is to fill these gaps through reviewing the studies that might provide the same benefits of shading trees nearby buildings. Furthermore, for indoor greenery concepts, their effect on building indoor air quality will also be studied.

Therefore, the literature review was undertaken with the objectives of:

- Studying the possible greenery concepts for building designs.

- Determining the impact of different variables in each greenery system which influence the temperature and heat flux

- Determining the energy impacts of greenery systems on HVAC systems

In order to avoid a long list of references in the text, they were split into major and minor references. The major works are the critical sources that are used in the analysis and therefore are cited in the text. The minor works are not numbered but are used to draw the conclusions; thus presented in the appendix.

\section{Greenery concepts}

\subsection{Green roofs}

\subsubsection{Introduction}

Roofs allocate approximately $20-25 \%$ of the total urban surface [5]; therefore, greening them can have a significant influence at the building scale and at the city scale. The green roof is the most common greenery concept, mostly in use in European, North-American and also some tropical Asian countries. Germany is considered the world pioneer in developing green roof technologies [6]. A green roof is a combination of different supportive layers that provide conditions for growing vegetation on a flat or sloped rooftop. A green roof's layer from top to bottom include the vegetation layer, growing medium, filter, drainage (moisture retention), root barrier and finally waterproofing membrane on top of a structural deck [7].

In accordance with the type of usage, construction factors and maintenance requirements, green roofs are typically divided into three major groups: extensive, intensive and semi-intensive roofs. The extensive type has a relatively thin layer of growing medium of around 6-20 cm thickness, typically grows moss, sedums, herbs and grass and requires less maintenance. The intensive green roof needs a thicker depth of growing medium of about $20-100 \mathrm{~cm}$, requires irrigation and permanent maintenance. The semi-intensive green roof is a combination of the extensive and intensive types; however, the extensive type must represent $25 \%$ or less of the total green roof area (see Table 1). 
Table 1. Classification of green roofs according to type of usage, construction factors and maintenance requirements [8]

\begin{tabular}{|c|c|c|c|}
\hline & Extensive Green Roof & Semi-Intensive Green Roof & Intensive Green Roof \\
\hline Maintenance & Low & Periodically & High \\
\hline Irrigation & No & Periodically & Regularly \\
\hline $\begin{array}{l}\text { Plant } \\
\text { communities }\end{array}$ & $\begin{array}{l}\text { Moss-Sedum-Herbs and } \\
\text { Grasses }\end{array}$ & Grass-Herbs and Shrubs & $\begin{array}{l}\text { Lawn or Perennials, Shrubs } \\
\text { and Trees }\end{array}$ \\
\hline $\begin{array}{l}\text { System build- } \\
\text { up height }\end{array}$ & $60-200 \mathrm{~mm}$ & $120-250 \mathrm{~mm}$ & $\begin{array}{l}150-400 \mathrm{~mm} \text { on } \\
\text { underground garages }>1000 \\
\mathrm{~mm}\end{array}$ \\
\hline Weight & $60-150 \mathrm{~kg} / \mathrm{m}^{2}$ & $120-200 \mathrm{~kg} / \mathrm{m}^{2}$ & $180-500 \mathrm{~kg} / \mathrm{m}^{2}$ \\
\hline Costs & Low & Middle & High \\
\hline Use & Ecological protection layer & Designed Green Roof & Park like garden \\
\hline
\end{tabular}

Since the past three decades, in Europe and subsequently in North America, an expansion of green roof research and product development has been observed resulting in the publication of guidelines and standards for establishment methods and maintenance of green roofs. The most well-known and comprehensive set of guidelines for green roofs throughout Europe is the FLL guideline which was launched in 1982 in Germany and then translated into English in 2002 [9]. Since then a considerable number of studies, using different research methods like field experiments, numerical calculations or laboratory experiments, have been published. The benefits of green roofs for the urban-scale and the micro-scale are numerous. These include storm water management, extension of roof life, noise reduction, mitigation of urban heat island effect, and an increase of biodiversity. Other advantages include enhanced thermal performance and building energy efficiency, which are also the main focus of this study.

The climate conditions on rooftops are more severe compared to the conditions on ground level, which makes it more difficult for plants to grow or survive. Sedums are the most common type of ground covering plants on extensive green roofs. They are drought-resistant and offer a good coverage across the roof, providing minimum maintenance and easy installation [7]. However, it is important to find a balance between the survivability of species and green roofs' ability to provide valuable multiple services for the building and the surrounding ecosystem such as indoor air temperature reduction or enhanced biodiversity.

\subsubsection{The impact of green roofs on temperature and heat flux}

With regard to the thermal effect of vegetation, there are many parameters that have an effect on a green roof's performance: vegetation form, type and diversity, coverage ratio (CR), leaf area index (LAI), foliage height and plant's biological processes like photosynthesis, respiration and transpiration. 
Additionally, physical features of the growing medium like thickness, water content and density, as well as the site conditions including climate factors and roof insulation value, can also determine the impact of green roofs on temperature and heat flux.

\subsubsection{Evapo-transpiratory effect}

Evapotranspiration is one of the most important factors contributing effectively on the cooling potential of green roofs. It is the combination of two phenomena: evaporation and transpiration. The physical process in which water transfers from soil into the atmosphere is called evaporation. Transpiration is a physiological process in plants through which water escapes through the stomata on leaves or the pores of the skin into the environment. The evapotranspiration in green roofs depends on the characteristics of the canopy, growing medium and environmental factors. The experimental result by Feng et al. [10] revealed that from the total amount of heat gained by an extensive green roof, $58.4 \%$ is released through evapotranspiration process, $9.5 \%$ is used for photosynthesis; the remaining part is either released to the atmosphere by long-wave radiative exchange between the canopy and the environment or absorbed by the growing medium. In line with the previous study, Lazzarin et al. [11] found the cooling role of evapotranspiration very effective. Based on their field experiment, in case of dry substrate when the evapotranspiration is very limited, a green roof reduced the heat gain by $60 \%$, mostly due to solar reflection and absorption by the canopy and the growing medium. For a wet substrate, instead of $40 \%$ entering heat flux into the building, a slight outgoing heat flux resulted due to an increase in evapotranspiration rate.

Environmental factors also play an important role in the cooling effect of green roofs. Theodosiou [12] addresses the importance of wind speed and relative humidity (RH) for the cooling ability of green roofs. He explains that a dry environment increases the evapotranspiration rate, while wind accelerates this trend by removing humidity from the vicinity of vegetation, therefore enhancing the cooling effect. In line with the previous study, Tsang \& Jim [13] measured the highest amount of transpiration during early autumn when the weather is dry and solar radiation is considerably high.

\subsubsection{Shading effect}

Wong et al. [14] carried out a field experiment on top of a low-rise building with an intensive green roof, covered with grass, shrubs and trees in order to measure the direct (roof surface temperature and heat flux) impact of rooftop greening in a tropical climate, Singapore. During the afternoon with high solar radiation $\left(1400 \mathrm{~W} / \mathrm{m}^{2}\right)$, maximum surface temperate for the bare roof was around $57{ }^{\circ} \mathrm{C}$, considerably higher than $42{ }^{\circ} \mathrm{C}$ for bare soil and $25.6{ }^{\circ} \mathrm{C}$ under a dense vegetation layer. Similar conclusions were achieved by Morau et al. [15] through a field study in a tropical humid island on the southern hemisphere. The results demonstrated that the surface temperature differences under an extensive green roof was considerably lower $(73-35=38 \mathrm{~K})$, and the heat flow was reduced in a range between 51-63\%. Depending on the growing ability of different species (coverage ratio) and their shading coefficient, the efficiency of green roofs could be slightly different for each study.

Based on mathematical calculations, Barrio [16] found that leaf area index (LAI) and leaf angle distribution (LAD) are two important factors, reducing the solar radiation through the canopy effectively. LAI is a measurement index for canopy foliage density and is broadly defined as the total amount of leaf area $\left(\mathrm{m}^{2}\right)$ in a canopy per unit ground area $\left(\mathrm{m}^{2}\right)$. LAI ranges from zero for bare ground to over fifteen for coniferous canopies. The second important physical characteristic of plant canopy, LAD refers to the angular orientation of the leaves. In Barrio's experiment, the results show that plant species with large foliage and horizontal leaves have the most solar shading effect. Furthermore, Wong 
et al. [14] measured the impact of foliage density on heat gain/lost during a typical day. There was no heat gain observed under dense foliage (shrubs) during the whole day and the maximum amount of heat lost was also achieved by utilizing shrubs. According to Schumann [17], green roofs with higher LAI reduce higher amount of solar radiation that passes through the canopy. She found that increasing the LAI form one to five can reduce solar transmittance from $40 \%$ to $5 \%$. Sailor et al. [18] suggested that in cooling dominated climates, LAI is the most important parameter which helps to reduce cooling needs, mostly through foliage transpiration and solar shading. Similarly, Jaffal et al. [19] developed a model for a green roof's thermal behaviour. They considered four values of LAI $(0.5,2,3.5$ and 5). Their results show that increasing the value of LAI will lead to a reduction of summer indoor air temperature and cooling demand. Wong et al. [20] found a lower temperature under a thick canopy layer and conversely a higher temperature under sparse foliage ranging from $26.5^{\circ} \mathrm{C}$ to $36^{\circ} \mathrm{C}$. In line with the previous studies, the result of a mathematical model developed by Kumar \& Kaushik [21] conforms that the heat flux through the green roof and the indoor air temperature will reduce by increasing the density of the foliage (or leaf area index).

Fang [22] provided an indoor controlled environment to plot a map that shows the correlation between coverage ratio (CR) and total leaf thickness (TLT) and their effects on indoor air temperature reduction in summer. He found that for a smaller percentage of vegetation coverage, a higher TLT was needed for thermal reduction; therefore, these factors have a complementary correlation.

\subsubsection{Thermal insulation}

Many researchers investigated the effect of different growing medium parameters on the thermal efficiency of green roofs, including the thickness of the growing medium, its relative density, along with the moisture content. A comparison was made by Permpituck \& Namprakai [23] between two sets of green roofs with 10 and $20 \mathrm{~cm}$ soil thickness and a bare roof. Their result shows a significant reduction in heat transfer (59\% and 96\%) and energy consumption (31\% and 37\%) respectively for 10 and $20 \mathrm{~cm}$ soil depth compared to a bare roof. Other researchers also emphasise the importance of soil thickness on reducing the heat flux through a green roof similar to the study by Sailor et al. [18].

In other studies, Tsang \& Jim [13] conducted a theoretical model to estimate the thermal performance of a green roof in the tropical climate of Hong Kong. Through a sensitivity analysis, they found that albedo value of the green surface, air convection rate near the canopy and the water content of growing medium are the three main factors that can regulate heat storage in a green roof. Halving the albedo value increasing heat storage by more than $70 \%$. Furthermore, increasing the air convection rate near the canopy can effectively enhance evapotranspiration from the foliage and soil layer, hence improve the latent heat dissipation. The result shows that increasing the air rate from 12 to $16 \mathrm{~m} / \mathrm{s}$, will reduce the heat storage $45 \%$. Finally, they found a $24 \%$ heat storage reduction when the moisture content of the growing medium increased from $30 \%$ to $60 \%$.

The water content of growing medium influences the thermal performance of a green roof in each season in a different way. During the hot seasons or in equatorial climates (where the summer-winter temperature differences is not considerable), a wet green roof can increase the heat dissipation through evapo-transpiratory cooling. Therefore, it reduces the need for indoor cooling [16]. However, in winter, thermal resistance of a green roof improves with less water content in the growing medium [24] due to water having a higher thermal conductivity than air [25]. Through a predictive numerical model developed by Lazzarin et al. [11] similar conclusions were achieved for winter conditions. They found that a wet green roof has $40 \%$ more outgoing heat flux compared to a typical insulated roof. Although, 
Lazzarin et al. might not include cold winters where plants go dormant, thus there is no plant transpiration and there is just evaporation from the soil.

Del Barrio [16] found that a reduction in soil density leads to additional air pockets inside the soil, which in turn improves the thermal insulation properties of the soil layer. Similar conclusions by Lin \& Lin [26] confirmed the findings of Del Barrio. Among four different plant substrates, the one with highest porosity provides the best thermal insulation for the green roof due to the formation of air pockets and water holding capacity. Based on other studies, there are evidences that green roofs with higher diversity and complexity (different plant type form and size) demonstrate lower temperature fluctuations below their canopy and enhance the roof insulation through the formation of air pockets. According to Wong et al. [14], similar amount of heat flux were measured for a roof covered with bare soil and with plants at night. It indicates that foliage has limited effect on outgoing heat flux during nights compared to growing mediums that have better thermal insulation properties. Therefore, it could be assumed that the thermal insulation properties of a green roof is mostly connected to the insulation properties of the growing medium than foliage.

\subsubsection{The energy impact of green roofs on HVAC systems}

A well-insulated one storey office building is modelled by Ascione et al. [27] to investigate green roofs' potential on reducing the energy demand for air-conditioning systems in European climates. Based on the modelling results in cooling dominant climates for example in Spain and Italy, green roofs can reduce the annual primary energy demand (for cooling \& heating) by maximum 8-11\%. In heating dominant climates like the Netherland, UK and Norway, the maximum annual energy reduction is between 6-7\%. In a mediterranean climate, Santamouris et al. [28] carried out a modelling on a twostorey air-conditioned nursery building. The energy saving potential of a green roof system with $40 \%$ CR was simulated for the top floor and for the whole building. They found the monthly cooling load reduction for the whole building between 6-33\% and more effectively for the top floor in the range of $12-76 \%$ when the building is insulated. These large energy saving differences can be influenced by several factors in simulation settings like the value of roof insulation, building dimensions, ratio of window to wall, green roof components and climate conditions. Moreover, based on their experiment, green roofs slightly increase the heating demand (3-9\%) for a bare roof with insulation but reduce the heating demand for a non-insulated bare roof.

In accordance with the previous study, Jaffal et al. [19] conducted simulations on a single-family house with roof insulation in three European cities (Athens, La Rochelle and Stockholm). While green roofs have no impact on the heating demand in temperate climates, an increase of $8 \%$ was observed in mediterranean climates. This increase occurs as a result of shading and evaporanspiration effect of roof greening. However, in Stockholm with a higher latitude and a colder climate, the additional insulation effect of the green roof reduced the heating demand by $8 \%$. This means in cold climates where plants go dormant, the impact of shading and evaporanspiration is negligible compared to insulation effect. Furthermore, their investigation regarding the cooling effect of green roofs shows a dramatic reduction of cooling demand in Athens by around $52 \%\left(13.9 \mathrm{kWh} / \mathrm{m}^{2}\right)$. In La Rochelle, the reduction was less significant in absolute value $\left(2.4 \mathrm{kWh} / \mathrm{m}^{2}\right)$ but it was higher in relative value $(96 \%)$. In Stockholm, the cooling demand is negligible, therefore the green roof has no impact on the cooling demand.

As it was mentioned before, roof insulation level can influence the thermal performance of a green roof considerably. The correlation between a building's roof insulation and the energy saving potential provided by green roofs has been investigated by many researchers. In a temperate climate, Jaffal et al.'s [19] experiment on the impact of roof insulation shows a heating demand reduction of $48 \%$ for the 
uninsulated green roof. However by adding a $10 \mathrm{~cm}$ insulation layer the thermal effect of the green roof on the heating demand becomes negligible. Furthermore, the effect of a green roof on total energy demand decreases with higher levels of roof insulation. The total energy demand reduced from $50 \%$ for non-insulated green roof to $3 \%$ for the building with $30 \mathrm{~cm}$ of insulation below the green roof. According to another simulation study reported 12 years earlier in a mediterranean climate by Niachou et al. [29], the energy saving for cooling and heating load both are estimated around $45 \%$ when the roof has no insulation layer. However, by adding a thick layer of insulation, green roofs' energy saving percentage dropped surprisingly to $0 \%$ for cooling load and $2 \%$ for heating.

Other studies show the same trend, although the figures were slightly different. The limitations of building energy modelling software (boundary conditions, crudeness of the assumptions) combined with their paradigm shift in the current years can cause a little discrepancies in studies reported earlier. Generally, it can be summarized that old buildings with poor insulation level could receive the highest energy saving by utilizing green roofs. However, this does not mean that a green roof individually can act as an insulation layer for a roof especially in cold climates.

Ascione et al. [27] analyse the economic feasibility of green roofs compared to a cool roof in six European cities from cold northern cities to hot southern mediterranean areas. They concluded that green roofs are not an economic energy efficient strategy in European climates, when considering the investment and maintenance costs. However other large scale benefits on UHI, air pollution or rainwater management could justify the application of green roofs.

\subsection{Vertical greening}

\subsubsection{Introduction}

The greening of building facades has been suggested as a promising solution to make dense cities more sustainable [30]. Typically, the vertical skin of buildings is larger than the roof area. This fact emphasizes the importance of vertical greening systems, specifically for tall building typologies. The concept of vertical greening dates back to Babylonian civilization and the construction of the Hanging Gardens. Although, the application of climbing plants over a wall is not a new trend, the systems and the purpose of using them has changed over the last few decades. Historically, green walls were used for ornamental or horticultural purposes [31] but currently vertical greening systems, in line with other passive techniques, are used for their sustainability benefits.

When searching for the most appropriate vertical greening concepts for energy-saving, it is important to consider the type of system along with the influential factors on its operation. Currently, vertical greening systems can be classified into two main groups according to their establishment method, maintenance and operation: green façades and living walls. Living walls compared to green facades have a more complex structure including special supporting elements, growing media and irrigation systems to serve a large diversity of plants. Therefore, they are usually more expensive and require higher maintenance [32]. However due to the modular structure of living walls, plants can be pre-cultivated and then transferred to their place, as a result of which they can grow more efficiently [33]. In addition, in case of any mortality in one module, the proposed section can be replaced easily. As can be seen, the definition of each vertical greening system is described in Table 2. 
Table 2. Vertical greening systems, definitions and their characteristics [32, 34].

\begin{tabular}{|c|c|c|c|}
\hline & $\begin{array}{l}\text { Green } \\
\text { wall } \\
\text { system }\end{array}$ & Definition & Characteristics \\
\hline \multirow[t]{2}{*}{$\begin{array}{l}\text { Green } \\
\text { facade }\end{array}$} & $\begin{array}{l}\text { Direct } \\
\text { façade } \\
\text { greening }\end{array}$ & $\begin{array}{l}\text { This is counted as the traditional way of } \\
\text { greening facades. In this system climbing } \\
\text { plants are directly connected to the façade and } \\
\text { using building materials as a support. Plants are } \\
\text { mainly rooted in the ground or planter boxes. }\end{array}$ & $\begin{array}{l}\text { - Climbing plants can hardly grow up } \\
\text { to } 25 \mathrm{~m} \text { without supporting structure } \\
\text { and it takes a long time. } \\
\text { - They accelerate façade materials } \\
\text { deterioration and make maintenance } \\
\text { more difficult. }\end{array}$ \\
\hline & $\begin{array}{l}\text { Indirect } \\
\text { façade } \\
\text { greening }\end{array}$ & $\begin{array}{l}\text { In this system for providing a gap between the } \\
\text { façade and the green layer, some structural } \\
\text { supports e.g. wire, mesh or trellis are used. } \\
\text { Plants can root in the ground, on the roof or in } \\
\text { substrates attached to the wall. }\end{array}$ & $\begin{array}{l}\text { Double skin green façade increases } \\
\text { the insulation properties of green } \\
\text { walls by introducing a stagnant air } \\
\text { layer between wall and green layer, } \\
\text { protects the facade materials from } \\
\text { demolition and supports plants to } \\
\text { grow faster. }\end{array}$ \\
\hline \multirow[t]{2}{*}{$\begin{array}{c}\text { Living } \\
\text { wall }\end{array}$} & Living wall & $\begin{array}{l}\text { Living walls consist of modular pre-cultivated } \\
\text { panels; each contains a growing medium and } \\
\text { irrigation system to provide all of the nutrients } \\
\text { for plants. They have also a waterproof layer to } \\
\text { isolate the façade from moisture penetration. }\end{array}$ & $\begin{array}{l}\text { In these systems a large variety of } \\
\text { plants can be added including ferns, } \\
\text { small shrubs, and perennial flower. } \\
\text { - If necessary, the modular structure } \\
\text { makes the replacement of plants } \\
\text { easier. }\end{array}$ \\
\hline & $\begin{array}{l}\text { Indoor } \\
\text { living wall } \\
\text { (Bio-filters) }\end{array}$ & $\begin{array}{l}\text { Bio-walls are indoor vertical greening systems } \\
\text { that are mostly used for filtration of the indoor } \\
\text { air and enhancement of aesthetic values of the } \\
\text { indoor environment especially in office spaces. } \\
\text { They can purify the air passively through } \\
\text { natural convection or by using a fan to facilitate } \\
\text { the circulation and improve its efficiency. }\end{array}$ & $\begin{array}{l}\text { - These systems need a high } \\
\text { maintenance and are more expensive } \\
\text { compared to green facades. }\end{array}$ \\
\hline
\end{tabular}

\subsubsection{The impact of green walls on temperature and heat flux}

Three main factors are recognized by researchers as the key parameters which determine the impact of vertical greening systems as a passive technique for energy saving in a building: the cooling effect of vegetation and substrate through evapotranspiration, the thermal insulation effect through making a microclimate environment between the canopy and building envelope and the shadow effect of the vegetation layer.

\subsubsection{Evapo-transpiratory effect}

Wong et al. [35] conducted a field work to observe the influence of different vertical greening systems on ambient air temperature. The best cooling effect was measured in the vicinity of living wall system with a reduction of $3.3{ }^{\circ} \mathrm{C}$ and $1.6{ }^{\circ} \mathrm{C}$ respectively at the distance of 15 and $30 \mathrm{~cm}$ from the green wall. For up to $60 \mathrm{~cm}$, all of the vertical greenery systems have no longer influenced the ambient temperature. This indicates that a green facade becomes less hot compared to a bare wall, hence not only radiates less heat but also cool the ambient environment through evapotranspiration. Consequently, a cooler ambient temperature around a building can translate to a decrease in the cooling load of the building. They also found that, with appropriate use of greenery on buildings, the micro-climate can improve noticeably. Perini et al. [34] have also measured the ambient air temperature differences in the vicinity of three vertical greening systems (direct, indirect and LW). The results show no remarkable air temperature differences for all of the greening systems at the distance of $10 \mathrm{~cm}$ to one meter away from the façade. These differences between two studies can be explained by the influence of environmental factors on evapotranspiration rate. In Perini et al.'s experiment, the measurements were 
carried out in a temperate climate during autumn when direct solar radiation is considerably low, therefore plant's transpiration would be little compared to the hot summer conditions.

Vertical greening systems can reduce the indoor air temperature by evapo-transpiratory cooling effect of vegetation layer or growing media. By doing so, the cooling load of the building can be reduced. Through a field work, Sunakorn \& Yimprayoon [36] measured the indoor air temperature differences for two west oriented rooms one with indirect vertical greening system and a room without. The green wall was made from climbing plants with 4-5 LAI and 90\% coverage, with $70 \mathrm{~cm}$ distance from the wall. The experiment was done at the beginning of summer in a hot and humid tropical climate. To assess the impact of wind velocity on the thermal performance of vertical greening system, two scenarios of ventilation were applied: with natural ventilation and without ventilation. The average indoor air temperature differences between the two rooms for ventilated and not ventilated scenarios were $0.9 \mathrm{~K}$ and $0.3 \mathrm{~K}$ respectively. It shows that using natural ventilation can slightly improve the cooling effect of vertical greening system due to higher evapotranspiration rate. The result of Chen et al. [37] study confirms the previous findings. In a lab environment with no ventilation, the mean temperature of the indoor space only reduced by $0.4{ }^{\circ} \mathrm{C}$ through the application of LWS.

Indoor active living walls have been suggested as a good alternative for improving the building's indoor air quality. These systems can work individually or together with the air-conditioning systems. Although their installation and maintenance is expensive and complex, they can provide the same benefits as passive living walls [38]. The cooling effect of indoor living walls results from the combination of evaporation from constant irrigation and transpiration from vegetation. Moreover, their capacity in Oxygen production and bio-filtration of volatile organic compounds (VOCs) and $\mathrm{CO}_{2}$, reduce the need for air filtration [39].

A field experiment was carried out by Fernandez-Canero et al. [40] in a mediterranean climate, Spain. They installed an indoor living wall with four different substrates (two from organic origin and two synthetic) to determine their impact on indoor air temperature and humidity. The experiment was carried out during a warm period of the year when the building was occupied by normal activities. Their measurements of the variation in indoor air temperature show a reduction of the ambient air temperature by $4{ }^{\circ} \mathrm{C}$. The temperature reduction was most remarkable in the vicinity of the vegetation with a fall up to $7{ }^{\circ} \mathrm{C}$. In addition, an average increase in indoor humidity near the living wall of around $15 \%$ was observed. By taking into account the role of living walls in the humidification and the cooling of the indoor environment, they can contribute in providing comfortable conditions for the occupants, reducing the need for air-conditioning systems especially in hot and dry climates.

\subsubsection{Shading effect}

A green wall can protect the building envelope from overheating through shading. The total solar radiation striking a green wall depends on the physical characteristics of the canopy, it will be transferred into these three ways: reflected to the atmosphere, or absorbed by the canopy or transmitted through the leaf [41]. The shading effect of a vertical greening system depends strongly on the density of the foliage and the coverage ratio. An experiment was setup by Ip et al. [42] to investigate the shading coefficient of a deciduous climbing plants that covered the southwest windows of a building in the temperate climate of the UK. The results showed solar transmittance through one leaf layer initially being around $45 \%$, dropped to $12 \%$ when it passed over five leaf layers.

There are some studies indicating the role of plant's shading coefficient in ameliorating the thermal performance of a building. Overall thermal transfer value (OTTV) is an indicator for the thermal performance of a building envelope. According to Building Control Regulations published in 1979, all 
air conditioned buildings are required to be designed with an OTTV of not more than $45 \mathrm{~W} / \mathrm{m}^{2}$ [43]. Wong et al. [44] simulated the effect of vertical greening systems on the OTTV of a 20-storey hypothetical building that is fully covered by glass. They found that building's OTTV reduced significantly (40\%) when the plants coverage ratio was 50\%, and the solar transmittance value was only $4 \%$. By increasing the shading coefficient from 0.5 to 0.98 , the envelop OTTV reduced to $21 \%$ and $0.6 \%$. Furthermore, they plotted a linear correlation between shading coefficient and LAI. It means that the higher value of LAI can be translated to less solar transmittance, hence grater thermal performance for the building.

Shading by vertical greenery systems leads to a reduction of external surface temperature and the consequent incoming heat flux through building envelope. Wong et al. [35] conducted a field work to observe the influence of different vertical greening systems on the surface temperature of nine free standing concrete walls in an open environment in Singapore. The substrate thickness and the foliage height were different in each vertical system. The maximum reduction observed on a sunny day was around $10.9{ }^{\circ} \mathrm{C}$ for living walls with modular panels. However, it should be noticed that in this study both sides of the concrete wall are exposed to outdoor climate conditions. Therefore the observed figures may be slightly different for a real building. For example, based on a field measurement, Chen et al. [37] have addressed the cooling effect of LWS on the exterior wall more effective by a maximum reduction of $20.8^{\circ} \mathrm{C}$ compared to the bare wall in a hot and humid conditions.

A field experiment in the mediterranean continental climate of Spain was performed by Nori et al. [45] to determine the efficiency of a LWS on the exterior wall of a highly insulated building both in a sunny day and a cloudy day. They found the efficiency of a LWS is extremely influenced by solar radiation intensity. On a sunny day with a maximum vertical radiation of $692 \mathrm{~W} / \mathrm{m}^{2} \mathrm{~K}$, the highest recorded temperature was $46.7^{\circ} \mathrm{C}$ for the conventional façade, and $22.1^{\circ} \mathrm{C}$ for the green façade. In a cloudy day with less solar radiation (MVR: $140.8 \mathrm{~W} / \mathrm{m}^{2} \mathrm{~K}$ ), the temperature differences between the two façades was only 3.1 K. Mazzali et al. [46] also reported the external surface temperature differences of three LWSs with a range between $1 \mathrm{~K}$ (a cloudy day) to $20 \mathrm{~K}$ (a sunny day) affected by the amount of solar radiation. Thus, a green wall can improve the building's thermal performance in a different range, depending on the outdoor conditions and, more importantly, the solar radiation (sky clearness and radiation angular distribution).

Perini et al. [34] conducted a field measurement in the Netherlands, a temperate climate, and compared the surface temperature differences between a bare wall and three different vertical greening systems. Small temperature differences were obtained for indirect $(20 \mathrm{~cm}$ air cavity) and direct (attached) green walls. Living wall systems with planter boxes, compared to other greenery systems, had a higher temperature difference of around $5 \mathrm{~K}$. Among nine different green wall systems in Wong et al.'s study, LWS with modular panels contribute more effectively on surface wall temperature reduction [35]. This is likely caused by higher shading effect by planter boxes beside higher evapotranspiration duo to constant irrigation in living wall systems.

\subsubsection{Thermal insulation}

The formulation of microclimate environment in the air cavity between a building façade and a green wall, acting as a thermal buffer, hence reducing the heat flux through the building envelope by regulating the ambient air temperature and wind speed. According to Nori et al. [45], a green façade has higher surface temperature compared to a bare façade during night times when there is no solar radiation. This can be translated into the thermal buffering ability of intermediate microclimate and its influence on deceleration of the heat loss through the building envelope. 
Pérez et al. [47] conducted a field work on a detached green wall, assembled on a steel structure with $80-150 \mathrm{~cm}$ distance form northwest, southwest and southeast façade in the dry mediterranean continental climate. The study was done during spring and winter when the foliage coverage was around $62 \%$. The amount of transmittance through the foliage range from $37 \%$ in spring to $3 \%$ in summer when the green wall has the highest coverage ratio. Furthermore, they measured the role of microclimate environment in the intermediate spaces. They found lower temperatures (maximum $2{ }^{\circ} \mathrm{C}$ ) and higher humidity (maximum 7\%) in the intermediate space compared to the ambient environment. Other authors have also addressed a similar trend for temperature reduction in the intermediate space of a LWS, as with the study by Chen at al. [37]. In this study, they observed the influence of natural ventilation and the air cavity thickness on the cooling effect of microclimate environment in the intermediate space. The maximum temperature reduction of air cavity was found around $9.7^{\circ} \mathrm{C}$ for the LWS that was sealed in all directions and located with $3 \mathrm{~cm}$ distance from the wall.

Perini et al. [34] have also investigated the correlation of air cavity thickness with thermal insulation properties provided by green walls. They found that direct façade greening and living wall (with $4 \mathrm{~cm}$ air cavity) are more effective on reducing the wind speed around the building façade than indirect green wall (with $20 \mathrm{~cm}$ air cavity) due to shorter vegetation-wall distances. They also noted that a reduction of the air layer thickness of an indirect greening system by around 4-6 cm would improve its thermal insulation impact on building.

\subsubsection{The energy impact of green walls on HVAC systems}

Green facades can contribute effectively in reducing the indoor temperature by absorbing the solar radiation for growth and biological processes. A reduction of indoor air temperature means a considerable energy-saving for air-conditioning during summer times. However shading by plants should not obstruct the passive heat gain through the building envelope during winter times otherwise it will increase the heating demand. Kontoleon \& Eumorfopoulou [48] modelled a green wall with 20 $\mathrm{cm}$ thickness on four main directions of a building during summer to predict the influence of green wall's orientation on reducing the cooling demand in a mediterranean climate. The highest and lowest influence was acquired through greening the west- and north-oriented walls with $20 \%$ and 5\% energy saving respectively. Therefore, selecting the wright orientation for plants on vertical surfaces can result in a remarkable energy saving for cooling loads during summer.

McPherson et al. [49] conducted a simulation study in four different climates to investigate the shading effect of vegetation on all surfaces (both roof and walls) on the energy demand of a building. They found that in cold climates the shading effect from an evergreen plant increases the annual heating cost by $21 \%$. If deciduous plants were used, this negative effect was diminished. Therefore, green roofs and walls can increase or decrease the building heating demand, depending on the winter outdoor conditions and, more importantly, the solar radiation (sky clearness and radiation angular distribution). Furthermore, in temperate and hot climates, dense shading over all surfaces of a building reduces the annual cooling cost by $53-61 \%$.

Through a computer modelling, Stec et al. [50] showed that the application of vegetation inside the cavity of a double skin façade can provide a comfortable indoor climate for a building. They compared the thermal performance of two shading devices inside a double-skin façade: a bio-shade and a blind. The result shows a lower temperature on the surface of the green layer $\left(35^{\circ} \mathrm{C}\right)$ compared to the blinds $\left(55^{\circ} \mathrm{C}\right)$ and up to $20 \%$ reduction in the energy use of air-conditioning systems. 


\subsection{Green balconies}

\subsubsection{Introduction}

A balcony is commonly defined as a platform that projects from the wall of a building and is surrounded by a railing, balustrade, or parapet. Haber [51] conducted a post-occupancy study on a highrise building and found that most of the complaints by high-rise dwellers originated from a lack of greenery and a sense of disconnection form the outside. Balconies can function as a mediator space to connect the indoor with the outdoor environment. They offer many benefits and advantages both for the people who lived inside a building and for the ecosystem. Balconies can provide a spectacular view to the city, urban park or natural greenery. They also enhance biodiversity and architectural interest and help to reduce rain water runoff. There are also some studies which indicate that balconies can add to the value of a building compared to a similar construction without balconies [52]. Over the last decades, new technologies have provided conditions for growing large trees up to three meters with a thick substrate of soil (1 meter) on balconies (e.g. Milan vertical forest project in Italy).

Besides all of the advantages that balconies offer a building, they can negatively contribute to heat gains and losses; and as a consequence increase the heating and cooling load for air conditioning systems. Balconies can act as a thermal bridge between the indoor and outdoor environment. According to energy simulations done by Ge et al. [53] on a balcony in a cold climate of Toronto, reducing the heat transfer through the balcony slab can decrease the heating and cooling demand by $5-13 \%$ and $1 \%$ respectively.

\subsubsection{The impact of green balconies on temperature and heat flux}

There has been limited research on a green balcony's contribution to energy saving for buildings. However, the number of studies that investigates the cooling or shading effect of neighbouring trees on a building is considerable. Therefore, the aim is to fill these gaps through reviewing the studies that might provide the same benefits for balconies such as shading trees nearby a building façade. There are many studies that show the application of plants around buildings, especially in front of the south elevation that can reduce peak energy consumption through controlling the solar radiation on a wall.

\subsubsection{Evapo-transpiratory effect}

Through a field experiment in a mediterranean climate, Papadakis et al. [54] measured the role of deciduous trees on regulating the microclimate environment when facing a southern elevation. The ambient air temperature was maximum $3{ }^{\circ} \mathrm{C}$ lower and that the relative humidity was up to $7 \%$ higher in the shaded area near the building façade.

\subsubsection{Shading effect}

Papadakis et al. [54] further studied the shading effect provided by trees on the wall. In their study, they compared two areas of an office building during summer: a shaded area with an un-shaded area. The peak solar radiation over the exposed area was measured around $600 \mathrm{~W} / \mathrm{m}^{2}$ though the corresponding value for shaded wall was less than $100 \mathrm{~W} / \mathrm{m}^{2}$. Berry et al. [55] carried out a field work on three identical building during summer and spring in southern hemisphere in Melbourne with an oceanic climate. As a reference one building was exposed but the west and north facing walls of the other two buildings were shaded separately by deciduous and evergreen potted trees. They used the collected data from field measurements to develop a model that predicted external wall surface 
temperature. According to their findings, both shading coverage and solar irradiance are the two main factors for quantifying the external wall temperature through the predictive model. Furthermore, the presence of shading trees can reduce the wall surface temperature and the ambient air temperature (within the intermediate space of wall and tree) up to $9^{\circ} \mathrm{C}$ and $1{ }^{\circ} \mathrm{C}$ respectively.

\subsubsection{Thermal insulation}

McPherson et al. [49] simulated the effect of a vegetation layer on the thermal performance of a building as an insulation against wind. Modelling result presented a 50\% reduction of wind speed nearby the building façade while it passed through a shading tree. Some studies have mentioned the insulation effect of shading trees during nights. According to Papadakis et al. [54] study, the wall surface temperature was slightly higher $\left(0.5-1{ }^{\circ} \mathrm{C}\right)$ in the vicinity of vegetation during the nights. This shows that the vegetation layer is a barrier against heat radiation from the building envelope to the atmosphere during the night, hence reducing the UHI. A similar trend was addressed in Berry et al.'s field experiment [55]. They found the air temperature between the wall and the shading tree, slightly warmer during the night (up to $1^{\circ} \mathrm{C}$ ) compared to the area without trees.

\subsubsection{The energy impact of green balconies (shading trees) on HVAC systems}

Shaded trees can make a microclimate close to the building façade through evapotranspiration, shading effect and wind control. It means that they can reduce the indoor air temperature, hence reducing the energy need for space cooling. However choosing the wrong configuration of shading trees either the orientation or the type of plants can result in a higher heating demand in winter. Several experimental and modelling studies have investigated the role of shading trees on building energy consumption. Many variables can influence the cooling potential of shading trees such as the number, height and orientation of trees, the distance of trees from the building, their coverage percentage over walls and roof, the density of foliage, the shading coefficient and the variability of experimented building designs.

Huang et al. [56] simulated the energy impact of 3 shading trees on summer cooling of residential buildings in different US cities. The highest energy saving was gained for Sacramenta with mediterranean climate. The simulation results suggested that shading on building can reduce annual cooling load by $53 \%$ for Sacramenta with 904 cooling hours demand. In subtropical desert climate of Phoenix with hot and dry summer (3647 cooling hours demand), the higher air temperatures may have negated the cooling effect of the shade with less energy saving by around 34\%. The calculated energy saving for Los Angeles was the least among all the climates due to insignificant requirement for cooling with 64 hours during a year.

However according to another study, in the cold climate of Canada, the modelling results showed that the annual cooling demand can be reduced by $90 \%$ in relative value [57]. For two monitored houses in Sacramenta, Akbari et al. [58] simulated the energy saving for summer cooling by around 30\% through shading the southern and western facing walls by sixteen trees. Simulation results by Simpson $\&$ McPherson [59], shows energy savings up to 50\% for cooling when shading trees are located in all directions except north in the mediterranean climate of California. In their simulation it was assumed that a deciduous tree can block $85 \%$ of solar radiation during the summer which is a high shading coefficient.

Based on empirical measurements, Pandit \& Laband [60] developed a statistical model that the electricity saving by shading trees could be estimated. Predictive results showed more than $14 \%$ energy saving for electricity consumption by a dense shade covering $50 \%$ of a typical house area during 
summer. However, in winter conditions with less shading coverage (20\%), electricity usage increased by $6 \%$ which might be due to less solar heat gain through building envelope and more dependence on artificial lightning instead of natural light in dark winter days. The modelling result by Nikoofard et al. [57] showed almost the same trend for winter conditions with an increase in heating demand by $10 \%$.

The result of a field experiment by Laband \& Sophocleus [61] reported the cooling potential of shading trees more significant compared to computer simulations. They compared the electricity consumption of two identical buildings one exposed and the other shaded during hot times of the year. They set the indoor air temperature on $22^{\circ} \mathrm{C}$ and use air conditioning units for cooling the indoor air. The AC units were directly connected into data loggers to measure electricity consumption for each building. It was found that for the exposed building, the electricity usage for indoor cooling was 2.6 times more than the shaded building. However it is not possible to generalize these finding, as the energy saving might be varied in case of any change in roof colour, or insulation level.

A few studies have investigated the configuration of canopies with the aim to achieve the highest energy saving. McPherson et al. [49] suggested that in cold climates the orientation of planting should be in such a way that it reduces the cold winter wind and provides direct solar radiation to southern and eastern walls. In the temperate climate, the same trend emerged, although the vegetation layer should not block the summer winds. In contrast, in hot climates, both shading and wind velocity should be enhanced by using an appropriate type of plants. Simpson \& McPherson [59] simulated the energy impact of shading trees on building air-conditioning in California. The largest annual and peak energy saving gained by shading the west-facing walls. Pandit \& Laband [60] highlighted shading density as an important factor besides shading coverage. With the same value for shading coverage, a dense shade can provide more cooling effect compared to moderate or light shade. However, in order to provide a better shading, trees should be close and tall enough to shade the external walls and possibly the roof.

\subsection{Sky gardens}

Over the last decades, sky gardens (Sky courts or podium gardens) have been introduced as a new greenery concept mostly integrated into high-rise buildings. There are different definitions for sky gardens. Osmundson [62] defines it as a vegetated open space that may be located at any height, and is separated from the ground level by a man-made structure to provide benefits for the environment and for humans. Ong [63] defines a sky garden as a green space that is located above the ground level and can be in the form of a podium garden on intermediate floors of a building or a roof garden at rooftop level.

Through reviewing some examples of green high-rise projects over the world, the three most common places in buildings where sky gardening is applied are: on a structure on top of the roof, on intermediate floors (on podiums) and on the sky bridges.

There are some differences between a common green roof system and a rooftop garden due to differences in accessibility and exposure to sun and wind. In sky gardens, the rooftop greenery system is usually placed on an external structure with some distance to the roof of the building (e.g. Marina bay sands hotel in Singapore). Between the three aforementioned locations for sky gardens, rooftop garden and sky-bridge are not directly connected with building envelope. Consequently, they probably could not provide the same direct thermal benefits like the other greenery systems such as green roofs or green walls. However, sky gardens may offer most of the benefits provided by other greenery concepts for the macro scale such as mitigation of urban heat island effect, enhanced biodiversity and removal of air pollutants, as well as storm water management and visual aesthetic improvement [64]. However, if these systems are broadly integrated into buildings, they might have some indirect energy 
benefits through cooling the ambient air, thereby reducing the need for air conditioning systems. A podium garden acts like a green roof but on intermediate levels of a building. Consequently, podium gardens can offer the same benefits provided by green roofs for the building scale and the city scale. Only variations in climatic factors like solar radiation or wind speed may create differences concerning their performance.

Compared to other greenery concepts, there have been surprisingly few studies that explore the effect of sky gardens on the building and the outdoor environment. Tian \& Jim [64] made a comparison between the distribution of two greenery systems, sky gardens and roof gardens, in the compact city of Hong Kong. They found that the total area of podium gardens was eight times higher compared with roof gardens. Easier accessibility, more visibility and less exposure to strong winds are some of the factors that make sky gardens more available in Hong Kong's high-rise buildings compared to green roofs. According to Tian \& Jim "sky gardens in Hong Kong are in the early stage of development, with low green ratios in most land uses and districts" (p. 306) [64]. Some of the barriers which limit the wide proliferation of sky gardens are: Social and economic factors, lack of knowledge and awareness, lack of incentives from governments and private sectors, technical issues and risks associated with uncertainty especially for buildings with more than twenty floors.

\subsection{Indoor sky gardens (Indoor greening)}

\subsubsection{Introduction}

Indoor sky gardens are indoor spaces like atriums with more than one-storey height and usually equipped with potted plants or big trees in thick soil substrates. Indoor plants offer the building inhabitants some of the same benefits as the experience of outdoor nature. Improvement of comfort conditions is one among the numerous benefits indoor vegetation can provide for the tenants.

\subsubsection{The impact of indoor planting on indoor air quality}

In urbanized societies, modern lifestyle caused people to spend over $80 \%$ of their time indoors for their daily activities [65]. Therefore, the importance of indoor air quality (IAQ) is growing due to its direct influence on human's health and productivity. Around 25\% of US citizens suffer from poor IAQ either in their workplace or at home [66]. In Australia, unhealthy indoor air have been posed considerable finances around $\$ 12$ billion annually due to workers absenteeism, less productivity and medical costs [67]. Globally, it is estimated that the number of deaths caused by poor IAQ is fourteen times higher than ambient air pollution [68]. As a result, US Environmental Protection Agency (EPA) determined IAQ as one of the top five public health concerns over the past decades [69].

Using ventilation (passive or active) can help to remove moisture and airborne pollutants from indoor spaces and provide health and comfort for the occupants. When a building is naturally ventilated through the openings (controlled) or the gaps around openings (uncontrolled infiltration), it is called passive ventilation. Active ventilation is referred to the application of mechanical devices for air extraction. Modern buildings are designed in a way that both passive leakage and active ventilation are reduced. Therefore, the potential for illnesses such as Sick Building Syndrome (SBS) increases. In Table 3 common air pollutants and their sources combined with sickness symptoms and the standard values for these pollutants are presented. Increasing the air change rate, removing air pollutants and purifying indoor air are effective solutions to cope with poor indoor air quality [69]. 
Table 3. Typical air pollutants in indoor environment $[66,70]$

\begin{tabular}{|c|c|c|c|c|}
\hline Air pollutants & Source & Sickness symptoms & $\overline{\text { ASHRAE standa }}$ & \\
\hline $\begin{array}{l}\text { Particles: dust, pollen, } \\
\text { viruses, bacteria, } \\
\text { moulds, fungi, cigarette } \\
\text { smoke }\end{array}$ & $\begin{array}{l}\text { Outdoor air, combustion, } \\
\text { carpets, human activity, } \\
\text { decaying building }\end{array}$ & $\begin{array}{l}\text { Irritation to eyes and/or } \\
\text { respiratory tissues, } \\
\text { allergies, cancer, indirect } \\
\text { effect through biological } \\
\text { production of toxins. }\end{array}$ & $\begin{array}{l}\text { Particles < } 2.5 \mu \mathrm{m}: \\
\mu \mathrm{g} / \mathrm{m}^{3} \\
\text { Particles < } 10 \mu \mathrm{m}: \\
\mu \mathrm{g} / \mathrm{m}^{3}\end{array}$ & 15 \\
\hline $\begin{array}{l}\text { - Gaseous pollutants: } \mathrm{CO} \text {, } \\
\mathrm{CO} 2, \mathrm{NO}_{\mathrm{x}} \text {, } \\
\text { formaldehyde, VOCs }\end{array}$ & $\begin{array}{l}\text { Combustion, human } \\
\text { activity, building } \\
\text { materials, furniture, } \\
\text { cleaning products, mold } \\
\text { development etc. }\end{array}$ & $\begin{array}{l}\text { Irritation to eyes and/or } \\
\text { respiratory tissues, } \\
\text { allergies, cancer, effects } \\
\text { on the respiratory liver, } \\
\text { immune, reproductive } \\
\text { and/or nervous system }\end{array}$ & $\begin{array}{l}\mathrm{CO}<9 \mathrm{ppm}(8 \mathrm{~h}) \\
\mathrm{CO}_{2}<5000 \mathrm{ppm} \\
\mathrm{NO}_{2}<100 \mu \mathrm{g} / \mathrm{m}^{3} \\
\text { Formaldehyde }<0.1 \\
\mathrm{mg} / \mathrm{m}^{3}(30 \mathrm{~min})\end{array}$ & \\
\hline - Radioactive gases & $\begin{array}{l}\text { Rock, soil, groundwater, } \\
\text { natural gas, mineral } \\
\text { building materials }\end{array}$ & Lung cancer & Radon: 4 pCi/liter & \\
\hline
\end{tabular}

Indoor vegetation like potted plants contributes to the purification of indoor air through biofiltration. Early findings have been demonstrated that potted plants can significantly contribute in air purification through their leaves [71]. Conversely, under chamber conditions in a lab experiment, Godish \& Guindon [72] observed the highest air filtration occurred when plants were defoliated. They suggested air filtration have been associated with soil medium factors. According to Fjeld \& Bonnevie "leaves, stems and roots work together with micro-organisms that live in the root zone, creating an ecosystem that can function as an air filtering system" ( p. 6) [73]. In addition, through photosynthesis plants take up carbon dioxide from the indoor air and release oxygen. As a result, they might reduce the need for ventilation hence contributing in energy saving.

Knowles et al. [74] found that more than $80 \%$ of indoor contaminants such as VOCs and $\mathrm{CO}_{2}$ can be removed through the use of indoor plants. In line with previous work, Tarran et al.'s [75] field measurements on sixty office buildings confirmed that potted plants can remarkably reduce total volatile organic compound (TVOC) loads in the indoor environment by $75 \%$. Furthermore, they found the impact of air conditioning rate and indoor light intensity insignificant on the process of bio-filtration. Pennisi \& van Iersel [76] performed a field experiment to define the reduction in ambient carbon dioxide levels resulting from the use of different species of indoor plants. They found that larger plants (mostly woody species) can take up higher quantities of $\mathrm{CO}_{2}$ compared to smaller herbaceous species.

The result of a post-occupancy analysis by Fjeld et al. [77] showed that indoor vegetation can alleviate symptoms of discomfort among office workers resulting from SBS. The score sum of symptoms were collected from 51 office workers in two scenarios, one time with plants in their offices and one period without. The result shows an overall improvement of around $23 \%$ when the respondents had plants in their offices. They also found that plants can reduce workers' complaints on some issues more effectively for example coughing, fatigue and dry skin; each decreased by $37 \%, 30 \%$ and $23 \%$ respectively.

\subsubsection{The impact of indoor planting on users' perception}

Taib \& Abdullah [78] conducted a study on a 21-storey high-rise office building in Singapore to investigate user perception of three different types of greenery during the hottest period of the year. The greenery concepts included: an indoor sky garden (on the $10^{\text {th }}$ floor), a green balcony (enclosed by three faces on the $12^{\text {th }}$ floor) and a green roof (on the $21^{\text {st }}$ floor). The first part of their study was on the usage of these green areas. Through a questionnaire survey they found that $96 \%$ of respondents agreed to the 
application of green spaces in high-rise office buildings. However, a different correlation seems to exist between respondents' desire to have greenery in their offices and the level of usage by them. Only half of respondents have visited the landscape gardens which shows a failure in their design.

An investigation of building design layouts shows that accessibility and visibility are two important factors which encourage people to use such green spaces. Therefore, while over half of respondents visited the indoor sky garden, less than one-fourth visited the green balcony and the green roof. According to Taib \& Abdullah "these findings supported an earlier statement by Alexander et al. [79] that people will visit urban greenery on a regular basis if it is within three to five minutes' walk of their home/workplace" (p. 637) [78].

In addition, they found a correlation between the usage of green spaces and the comfort level. At the indoor sky garden which has the highest number of visitors, 53.9\% of the participants felt comfortable. At the green balcony and the roof garden that had fewer visitors, respondents felt slightly comfortable respectively by $16.7 \%$ and $22.5 \%$. Some of the respondents suggested that providing some shaded areas could create a more comfortable environment at the rooftop garden. Moreover, Taib \& Abdullah [78] asked the respondents to prioritize their purpose of visiting green spaces. Interestingly, visitors use the green spaces with the same preferences. Their study illustrated that green areas in highrise office buildings mostly are used for resting, refreshing and for social activities.

\subsubsection{The energy impact of indoor planting on HVAC systems}

There is also some evidence that plants can increase the average humidity of the indoor air through evapotranspiration which may enhance the thermal comfort of the occupants, especially in hot interior spaces without ventilation. A study conducted by Lohr \& Bummer [80] revealed that when plants were placed in offices without ventilation the relative humidity (RH) increased significantly by around $15 \%$. They also showed that in a ventilated room plants only have a limited effect on average humidity (3$5 \%$ ). However, it should be mentioned that in both of the cases, the amount of RH did not exceed the recommended range of thirty to sixty percent. Additionally, some plant species have a higher rate of transpiration. According to Fjeld \& Bonnevie [73], plants with higher density and bigger leaf surface had a higher humidification effect

\section{Discussion and conclusions}

A literature review of the impact of greenery systems on thermal and energy performance of buildings demonstrates how little is known concerning the application of plants on areas like green balconies and sky gardens (indoor \& outdoor). Over the last decades, sky gardens have been introduced as a new greenery concept mostly integrated into high-rise building designs. Since tall buildings have been the corner stone of our cities, it is important to do more research on these greenery concepts with a focus on energy impact. Furthermore measurements on the impact of greenery systems have so far been limited to simulated models or filed studies on single buildings with time constraints. The variability of home design and occupant's behaviour in different studies make the generalization of results difficult. Using a large sample of homes with similar size and design strategies and possibly a longer period of study will help to have a more realistic overview on the energy impact of greenery systems in different climates.

In addition, a gap of knowledge exists in some areas that can be expanded in the future. Therefore, evaluating the effect of greenery systems on energy requires further study of: 
- Finding the optimal configuration of plant position (greenery concept), plant form (leaf area index and plant height), foliage shading (an evergreen and a deciduous type) and substrate properties (thicknesses, moisture content and density) for different climate types.

- Developing steady state analysis under controlled conditions to determine the influence of study conditions (building usage, morphology and its insulation level) besides the climatic factors on greenery systems seasonal energy performance

- Studying the influence of integrating greenery systems on energy saving for buildings.

- Discussion on cost effectiveness of different greening systems

\subsection{Impact of greenery concepts on comfort}

Indoor greenery concepts (indoor living walls and indoor sky gardens) mostly have benefits for indoor thermal comfort and specifically for indoor air quality (IAQ). According to this literature review, indoor plants can provide indoor comfort by means of three factors: purification, humidification and temperature reduction. Moreover, from a psychological point of view, plants can also provide comfort conditions by reducing stress and increasing health and well-being. The bio-filtration effect of leaves, stems and roots, can reduce the accumulation of VOCs in airtight buildings and provide a healthy environment for the building's occupants. Improving the indoor air quality leads to a reduction of the sick building syndrome, hence increasing the comfort and productivity of inhabitants. In addition, indoor plants can regulate the indoor temperature and humidity through evapotranspiration. Hot interior spaces without ventilation benefit most from this effect. Outdoor greenery systems such as green roofs, green walls, green balconies and sky podiums can also improve indoor thermal comfort through reducing heat fluxes and temperature fluctuations on building envelope. However in case of horizontal greenery systems their effect would be limited to top floors.

\subsection{Impact of greenery concepts on energy}

Greenery concepts can offer many benefits to a building. Among them, many researchers have been investigated the effect of different greenery systems on building energy consumption. Based on this literature review, greenery systems show different efficiencies over cooling and heating seasons. The maximum efficacy of greenery systems is reported during summer. Furthermore in sunny days or places with higher solar radiation, the efficiency of greenery systems is reported higher. In contrast, for winter conditions, different studies suggest controversial conclusions regarding the greenery systems' performance. It means that they can both save the energy or increase the heating need depending on the study conditions.

In cold climates when passive heat gain through the building envelope effectively contribute to energy saving, shading by vegetation will increase the heating demand. Furthermore, the age of building is an important factor. A large number of old buildings have poor insulation value. Then, adding an extra greenery layer can improve the insulation properties of buildings. As a result, when the positive effect of insulation by a greenery system is higher than the negative effect of shading, the application of greenery systems could lead to a reduction of heating load in winter.

The seasonal energy saving through application of greenery systems comes from three phenomena by plants or their substrate. While evapotranspiration and shading contribute effectively in the reduction of cooling load, the insulation effect of greenery systems can reduce winter heating demand. In table 4 the contribution of influential plant or substrate-related factors in summer cooling and winter heating is summarized. 
Table 4. The impact of greenery concepts on building energy consumption

\begin{tabular}{|c|c|c|c|c|c|c|}
\hline \multicolumn{2}{|c|}{$\begin{array}{r}\text { Greenery } \\
\text { system }\end{array}$} & 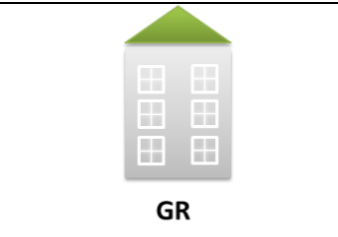 & 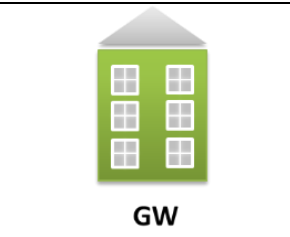 & 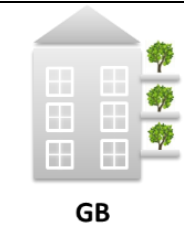 & 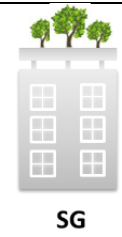 & $\frac{F^{4}}{\text { ISG }}$ \\
\hline \multirow{2}{*}{ 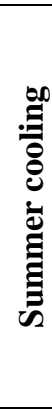 } & $\begin{array}{l}\text { Evapotrans } \\
\text { piration }\end{array}$ & $\begin{array}{l}{[+] \text { Leaf area index }} \\
{[+] \text { Substrate moisture }} \\
\text { content }\end{array}$ & $\begin{array}{l}{[+] \text { Leaf area index }} \\
{[+] \text { Substrate }} \\
\text { moisture content }\end{array}$ & \multicolumn{2}{|c|}{$[+]$ Leaf area index $* * * *$} & $\begin{array}{l}\text { [+] Leaf } \\
\text { size } \\
{[+]} \\
\text { Irrigation }\end{array}$ \\
\hline & Shading & $\begin{array}{l}++] \text { Coverage ratio } \\
{[+] \text { Foliage size }} \\
{[+] \text { leaf angle }} \\
\text { distribution }(\text { Horiz)* }\end{array}$ & $\begin{array}{l}\text { [+] Coverage ratio } \\
{[+] \text { Leaf area index }} \\
{[+] \text { Using LW }} \\
\text { system with planter } \\
\text { boxes }\end{array}$ & \multicolumn{2}{|c|}{$\begin{array}{l}\text { [+] Shading coverage } \\
\text { [+] Shading density } \\
\text { [-] Wall-vegetation } \\
\text { distance } \\
\text { [+] tree height } \\
\text { [+] Shading on west side }\end{array}$} & {$[\mathrm{N} / \mathrm{A}]$} \\
\hline \multirow{4}{*}{ :ְ } & $\begin{array}{l}\text { Evapotrans } \\
\text { piration }\end{array}$ & $\begin{array}{l}\text { [-] Substrate moisture } \\
\text { content** }\end{array}$ & $\begin{array}{l}{[-] \text { Substrate }} \\
\text { moisture content }\end{array}$ & \multicolumn{2}{|c|}{$\begin{array}{l}\text { [-] Substrate moisture } \\
\text { content } * * * * *\end{array}$} & {$[\mathrm{~N} / \mathrm{A}]$} \\
\hline & Shading & $\begin{array}{l}\text { [-] Shading coefficient } \\
\text { (deciduous plants) }\end{array}$ & $\begin{array}{l}\text { [-] Shading } \\
\text { coefficient } \\
\text { (deciduous plants) }\end{array}$ & \multicolumn{2}{|c|}{$\begin{array}{l}{[-] \text { Shading on south and }} \\
\text { E sides }\end{array}$} & {$[\mathrm{N} / \mathrm{A}]$} \\
\hline & Insulation & $\begin{array}{l}\text { [+] Substrate thickness } \\
{[-] \text { Substrate moisture }} \\
\text { content*** } \\
\text { [+] Plant diversity } \\
\text { [-] Substrate density }\end{array}$ & $\begin{array}{l}\text { [-] Wall-vegetation } \\
\text { distance }\end{array}$ & \multicolumn{2}{|c|}{$\begin{array}{l}{[+] \text { high coverage in the }} \\
\text { direction of cold winter } \\
\text { wind } \\
{[-] \text { Substrate moisture }} \\
\text { content }\end{array}$} & {$[\mathrm{N} / \mathrm{A}]$} \\
\hline & \multicolumn{6}{|c|}{$\begin{array}{l}\text { The effect should improve; } \mathbf{T} \text { The effect should decrease; [+] Higher value or quantity is needed; } \\
\text { [-] Lower value or quantity is needed } \\
\text { GR: Green roof, GW: Green wall, GB: Green balcony, SG: Sky garden, ISG: Indoor sky garden }\end{array}$} \\
\hline \multicolumn{7}{|c|}{$\begin{array}{l}\text { * Horizontal leaves have the most solar shading effect for green roofs } \\
* * \text { In winter a dry growing medium has less evapotranspiration, hence reducing the outgoing heat flux } \\
\text { *** A dry growing medium is a better insulator because water has higher thermal conductivity than air } \\
\text { **** This part is based on the effect of nearby shading trees due to a gap of knowledge for green balconies and sky gardens } \\
* * * * * \text { The impact of substrate moisture content is more considerable for a podium garden which is in a direct connection } \\
\text { with the building envelope and is negligible for green balcony and other forms of sky garden }\end{array}$} \\
\hline
\end{tabular}

\subsection{Suitability of greenery concepts for different climates}

The efficiency of greenery concepts also depends strongly on the climate factors such as temperature, relative humidity, solar radiation (sky clearness and radiation angular distribution) and wind velocity. A dry environment increases the evapotranspiration rate and wind accelerates this trend by removing humidity from the vicinity of vegetation. However, natural ventilation can reduce the thermal buffering ability of an indirect vertical greening system with long vegetation-wall distances. Furthermore, solar radiation is found the most important factor to influence the efficiency of greenery systems for summer cooling. Higher horizontal or vertical radiation means more temperature differences between the shaded and unshaded area, hence lower heat gain through the building envelope and more energy saving for cooling loads.

The geographical location of a place from the equator and cloud coverage determine the extent of heat gain through building surfaces. In places with high horizontal radiation (low latitude), application 
of green roofs is more beneficial for solar protection. In contrast, shading by vertical greenery systems is more applicable in places with high vertical radiation (high latitude). In table 5 the best orientation for the application of greenery systems concerning different climate conditions is summarized.

Table 5. Suitability of greenery concepts for different climates

\begin{tabular}{|c|c|c|c|}
\hline Cold & Temperate & Tropical & Hot and dry \\
\hline $\begin{array}{l}\text { The orientation of } \\
\text { greenery systems should } \\
\text { be in a way that it } \\
\text { reduces the cold winter } \\
\text { wind but provides direct } \\
\text { solar radiation to south } \\
\text { and east walls. }\end{array}$ & $\begin{array}{l}\text { The vegetation layer } \\
\text { should not block the } \\
\text { summer winds but } \\
\text { should reduce the cold } \\
\text { winter wind. } \\
\text { Furthermore, direct solar } \\
\text { radiation to south wall } \\
\text { and roof is necessary for } \\
\text { places with high heating } \\
\text { degree days. }\end{array}$ & $\begin{array}{l}\text { Both shading and wind } \\
\text { velocity should be } \\
\text { enhanced by using an } \\
\text { appropriate type of } \\
\text { plants. }\end{array}$ & $\begin{array}{l}\text { The highest amount of } \\
\text { shading and } \\
\text { evapotranspiration is } \\
\text { needed. Roof space, west } \\
\text { and east walls are places } \\
\text { that need the highest } \\
\text { solar protection. }\end{array}$ \\
\hline
\end{tabular}

\section{Appendix}

The following part representing the list of references that are not cited in this paper but have been used to draw the conclusions:

Alcazar, S., \& Bass, B. (2005). Energy performance of green roofs in a multi-storey residential building in Madrid, in: Greening Rooftops for Sustainable Communities, Washington, D.C.

Alexandri, E., \& Jones, P. (2008). Temperature decreases in an urban canyon due to green walls and green roofs in diverse climates. Building and Environment, 43(4), 480-493.

Castleton, H. F., Stovin, V., Beck, S. B. M., \& Davison, J. B. (2010). Green roofs; building energy savings and the potential for retrofit. Energy and Buildings, 42(10), 1582-1591.

Chan, A. L. S., \& Chow, T. T. (2013a). Energy and economic performance of green roof system under future climatic conditions in Hong Kong. Energy and Buildings, 64(0), 182-198.

Chan, A. L. S., \& Chow, T. T. (2013b). Evaluation of Overall Thermal Transfer Value (OTTV) for commercial buildings constructed with green roof. Applied Energy, 107(0), 10-24.

Cheng, C. Y., Cheung, K. K. S., \& Chu, L. M. (2010). Thermal performance of a vegetated cladding system on facade walls. Building and Environment, 45(8), 1779-1787.

Darlington, A., Chan, M., Malloch, D., Pilger, C., \& Dixon, M. A. (2000a). The Biofiltration of Indoor Air: Implications for Air Quality. Indoor Air, 10(1), 39-46.

Darlington, A. B., Dat, J. F., \& Dixon, M. A. (2000b). The Biofiltration of Indoor Air: Air Flux and Temperature Influences the Removal of Toluene, Ethylbenzene, and Xylene. Environmental Science \& Technology, 35(1), 240-246.

Darlington, A. B., Dixon, M. A., \& Arnold, K. A. (1996). The dynamics of ppCO2 and its fixation pattern in a partially closed biological system, SAE Technical Paper Series.

Darlington A. B., Dixon, M. A., \& Pilger, C. (1998). The use of bio-filters to improve indoor air quality: the removal of toluene, TCE and formaldehyde, Life Support and Biosphere Science, 5, 63-69.

Eumorfopoulou, E., \& Aravantinos, D. (1998). The contribution of a planted roof to the thermal protection of buildings in Greece. Energy and Buildings, 27(1), 29-36.

Eumorfopoulou, E. A., \& Kontoleon, K. J. (2009). Experimental approach to the contribution of plant-covered walls to the thermal behaviour of building envelopes. Building and Environment, 44(5), 1024-1038.

Fioretti, R., Palla, A., Lanza, L. G., \& Principi, P. (2010). Green roof energy and water related performance in the Mediterranean climate. Building and Environment, 45(8), 1890-1904.

Getter, K. L., Rowe, D. B., Andresen, J. A., \& Wichman, I. S. (2011). Seasonal heat flux properties of an extensive green roof in a Midwestern U.S. climate. Energy and Buildings, 43(12), 3548-3557.

Hoyano, A. (1988). Climatological uses of plants for solar control and the effects on the thermal environment of a building. Energy and Buildings, 11(1-3), 181-199. 
Köhler, M. (2008). Green facades- a view back and some visions. Urban Ecosystems, 11: 423-436.

Kokogiannakis, G., Tietje, A., \& Darkwa, J. (2011). The role of Green Roofs on Reducing Heating and Cooling Loads: A Database across Chinese Climates. Procedia Environmental Sciences, 11, Part B(0), 604610.

Koyama, T., Yoshinaga, M., Hayashi, H., Maeda, K.-i., \& Yamauchi, A. (2013). Identification of key plant traits contributing to the cooling effects of green façades using freestanding walls. Building and Environment, 66(0), 96-103.Llewellyn, D., Darlington, A., Dixon, M., \& Mallany, J. (2001). The Biofiltration of Indoor Air I: A Novel Reactor for a Novel Waste Gas Stream. Air Quality Solutions Ltd.

Lohr, V. I., \& Pearson-mims, C. H. (1996). Particulate matter accumulation on horizontal surfaces in interiors: Influence of foliage plants. Atmospheric Environment, 30(14), 2565-2568.

Nelson, M., \& Wolverton, B. C. (2011). Plants+soil/wetland microbes: Food crop systems that also clean air and water. Advances in Space Research, 47(4), 582-590.

Onmura, S., Matsumoto, M., \& Hokoi, S. (2001). Study on evaporative cooling effect of roof lawn gardens. Energy and Buildings, 33(7), 653-666.

Ouldboukhitine, S.-E., Belarbi, R., Jaffal, I., \& Trabelsi, A. (2011). Assessment of green roof thermal behavior: A coupled heat and mass transfer model. Building and Environment, 46(12), 2624-2631.

Sailor, D. J. (2008). A green roof model for building energy simulation programs. Energy and Buildings, 40(8), 1466-1478.

Simochi, S.L., \& Hites, R.A. (1995). Organic pollutant accumulation in vegetation, Environmental Science and Technology, 29: 2905-2914.

Spala, A., Bagiorgas, H. S., Assimakopoulos, M. N., Kalavrouziotis, J., Matthopoulos, D., \& Mihalakakou, G. (2008). On the green roof system. Selection, state of the art and energy potential investigation of a system installed in an office building in Athens, Greece. Renewable Energy, 33(1), 173-177.

Tabares-Velasco, P. C., \& Srebric, J. (2012). A heat transfer model for assessment of plant based roofing systems in summer conditions. Building and Environment, 49(0), 310-323.

Takakura, T., Kitade, S., \& Goto, E. (2000). Cooling effect of greenery cover over a building. Energy and Buildings, 31(1), 1-6.

Treesubsuntorn, C., \& Thiravetyan, P. (2012). Removal of benzene from indoor air by Dracaena sanderiana: Effect of wax and stomata. Atmospheric Environment, 57(0), 317-321.

Tuomainen M, Smolander J, Kurnitski J, Palonen J, \& O, S. (2002). Modelling the cost effects of the indoorenvironment. Paper presented at the Proceedings of indoor air, Monterey, California.

Wong, N. H., Kwang Tan, A. Y., Chen, Y., Sekar, K., Tan, P. Y., Chan, D., . . Wong, N. C. (2010). Thermal evaluation of vertical greenery systems for building walls. Building and Environment, 45(3), 663-672.

\section{References}

[1] United Nations. World urbanization prospect: the 2011 revision, New York. 2012; p. 4.

[2] Wood A. Trends and challenges in high-rise buildings in the 21st century, the international high-rise award 2012, council on tall buildings and urban habitat, Chicago. 2010.

[3] van den Dobbelsteen A. (2012). "High-rise buildings: a contribution to sustainable construction in the city" in H, Meyer \& D, Zandbelt (eds), High-rise and the Sustainable City. Amsterdam:Techne Press, pp. 120-47.

[4] Yeang K, Powell R. Designing the ecoskyscraper: premises for tall building design. The Structural Design of Tall and Special Buildings. 2007;16:411-27.

[5] Akbari H, Matthews HD. Global cooling updates: Reflective roofs and pavements. Energy and Buildings. 2012;55:2-6.

[6] Zhang X, Shen L, Tam VWY, Lee WWY. Barriers to implement extensive green roof systems: A Hong Kong study. Renewable and Sustainable Energy Reviews. 2012;16:314-9.

[7]Snodgrass EC, Snodgrass LL. Green Roof Plants: A Resource and Planting Guide. London:Timber Press, 2006.

[8] IGRA. (2012). Green roof types. In International Green Roof Association. Retrieved February 7, 2013, from http://www.igra-world.com/types_of_green_roofs/index.php.

[9] FLL. German Landscape Research, Development and Construction Society. Guidelines for the Planning, Construction and Maintenance of Green Roofing: green roofing guideline, 2008 edition.

[10] Feng C, Meng Q, Zhang Y. Theoretical and experimental analysis of the energy balance of extensive green roofs. Energy and Buildings. 2010;42:959-65.

[11] Lazzarin RM, Castellotti F, Busato F. Experimental measurements and numerical modelling of a green roof. Energy and Buildings. 2005;37:1260-7. 
[12] Theodosiou TG. Summer period analysis of the performance of a planted roof as a passive cooling technique. Energy and Buildings. 2003;35:909-17.

[13] Tsang SW, Jim CY. Theoretical evaluation of thermal and energy performance of tropical green roofs. Energy. 2011;36:3590-8.

[14] Wong NH, Chen Y, Ong CL, Sia A. Investigation of thermal benefits of rooftop garden in the tropical environment. Building and Environment. 2003;38:261-70.

[15] Morau D, Libelle T, Garde F. Performance Evaluation of Green Roof for Thermal Protection of Buildings In Reunion Island. Energy Procedia. 2012;14:1008-16.

[16] Barrio EPD. Analysis of the green roofs cooling potential in buildings. Energy and Buildings. 1998;27:17993.

[17] Schumann, L. 2007. Ecologically inspired design of green roof retrofit. M.S. Thesis, Biological Resources Engineering, University of Maryland, College Park. <http://hdl.handle.net/1903/7399>.

[18] Sailor D, Timothy B. Elley and Max Gibson. Exploring the building energy impacts of green roof design decisions - a modeling study of buildings in four distinct climates. Building Physics. 2011.

[19] Jaffal I, Ouldboukhitine S-E, Belarbi R. A comprehensive study of the impact of green roofs on building energy performance. Renewable Energy. 2012;43:157-64.

[20] Wong NH, Cheong DKW, Yan H, Soh J, Ong CL, Sia A. The effects of rooftop garden on energy consumption of a commercial building in Singapore. Energy and Buildings. 2003;35:353-64.

[21] Kumar R, Kaushik SC. Performance evaluation of green roof and shading for thermal protection of buildings. Building and Environment. 2005;40:1505-11.

[22] Fang C-F. Evaluating the thermal reduction effect of plant layers on rooftops. Energy and Buildings. 2008;40:1048-52.

[23] Permpituck S, Namprakai P. The energy consumption performance of roof lawn gardens in Thailand. Renewable Energy. 2012;40:98-103.

[24] Zinzi M, Agnoli S. Cool and green roofs. An energy and comfort comparison between passive cooling and mitigation urban heat island techniques for residential buildings in the Mediterranean region. Energy and Buildings. 2011;55:66-76.

[25] Lui K, Minor J. Performance evaluation of an extensive green roof. Proceeding of the Greening Rooftops for Sustainable Communities, Washington, D.C. 5-6 May 2005. Unpublished conference paper, 2005.

[26] Lin Y-J, Lin H-T. Thermal performance of different planting substrates and irrigation frequencies in extensive tropical rooftop greeneries. Building and Environment. 2011;46:345-55.

[27] Ascione F, Bianco N, de’ Rossi F, Turni G, Vanoli GP. Green roofs in European climates. Are effective solutions for the energy savings in air-conditioning? Applied Energy. 2013;104:845-59.

[28] Santamouris M, Pavlou C, Doukas P, Mihalakakou G, Synnefa A, Hatzibiros A, et al. Investigating and analysing the energy and environmental performance of an experimental green roof system installed in a nursery school building in Athens, Greece. Energy. 2007;32:1781-8.

[29] Niachou A, Papakonstantinou K, Santamouris M, Tsangrassoulis A, Mihalakakou G. Analysis of the green roof thermal properties and investigation of its energy performance. Energy and Buildings. 2001;33:719-29.

[30] Pérez G, Rincón L, Vila A, González JM, Cabeza LF. Green vertical systems for buildings as passive systems for energy savings. Applied Energy. 2011;88:4854-9.

[31] Dunnett N, Kingsbury N. Planting Green Roofs and Living Walls. London: Timber Press; 2008.

[32] Perini K, Rosasco P. Cost-benefit analysis for green façades and living wall systems. Building and Environment. 2013;70:110-21.

[33] Ottelé M, Perini K, Fraaij ALA, Haas EM, Raiteri R. Comparative life cycle analysis for green façades and living wall systems. Energy and Buildings. 2011;43:3419-29.

[34] Perini K, Ottelé M, Fraaij ALA, Haas EM, Raiteri R. Vertical greening systems and the effect on air flow and temperature on the building envelope. Building and Environment. 2011;46:2287-94.

[35] Wong NH, Kwang Tan AY, Tan PY, Chiang K, Wong NC. Acoustics evaluation of vertical greenery systems for building walls. Building and Environment. 2010;45:411-20.

[36] Sunakorn P, Yimprayoon C. Thermal Performance of Biofacade with Natural Ventilation in the Tropical Climate. Procedia Engineering. 2011;21:34-41.

[37] Chen Q, Li B, Liu X. An experimental evaluation of the living wall system in hot and humid climate. Energy and Buildings. 2013;61:298-307.

[38] Franco A, Fernández-Cañero R, Pérez-Urrestarazu L, Valera DL. Wind tunnel analysis of artificial substrates used in active living walls for indoor environment conditioning in Mediterranean buildings. Building and Environment. 2012;51:370-8.

[39] Wolverton BC, Wolverton JD. Plants and soil microorganisms: removal of formaldehyde, xylene and ammonia from the indoor environment. J. Mississippi Acad. Sci. 1993;38:11-15.

[40] Fernández-Cañero R, Urrestarazu LP, Franco Salas A. Assessment of the Cooling Potential of an Indoor Living Wall using Different Substrates in a Warm Climate. Indoor and Built Environment. 
[41] Tilley D, Price J, Matt S, Marrow B. Vegetated walls: thermal and growth properties of structured green facades. Final Report to Green Roofs for Healthy Cities-Green Walls Group, 2012.

[42] Ip K, Lam M, Miller A. Shading performance of a vertical deciduous climbing plant canopy. Building and Environment. 2010;45:81-8.

[43] BCA. (2004). Guidelines on envelope thermal transfer value for buildings. Issued by Commissioner of Building Control, Ver 1.01. Retrieved August 10, 2014, from

http://www.bca.gov.sg/PerformanceBased/others/ETTV.pdf.

[44] Wong NH, Tan AYK, Tan PY, Wong NC. Energy simulation of vertical greenery systems. Energy and Buildings. 2009;41:1401-8.

[45] Nori C, Olivieri F, Grifoni RC, Bedoya C. Testing the performance of a green wall system on an experimental building in the summer. PLEA2013 - 29th Conference, Sustainable Architecture for a Renewable Future, Munich, Germany. 2013.

[46] Mazzali U, Peron F, Romagnoni P, Pulselli RM, Bastianoni S. Experimental investigation on the energy performance of Living Walls in a temperate climate. Building and Environment. 2013;64:57-66.

[47] Pérez G, Rincón L, Vila A, González JM, Cabeza LF. Behaviour of green facades in Mediterranean Continental climate. Energy Conversion and Management. 2011;52:1861-7.

[48] Kontoleon KJ, Eumorfopoulou EA. The effect of the orientation and proportion of a plant-covered wall layer on the thermal performance of a building zone. Building and Environment. 2010;45:1287-303.

[49] McPherson EG, Herrington LP, Heisler GM. Impacts of vegetation on residential heating and cooling. Energy and Buildings. 1988;12:41-51.

[50] Stec WJ, van Paassen AHC, Maziarz A. Modelling the double skin façade with plants. Energy and Buildings. 2005;37:419-27.

[51] Haber GM. The impact of tall buildings on users and neighbors. In: Conway D, editor. Human response to tall building. Stroudsburg, PA: Dowden, Hutchinson, \& Ross, Inc. 1977:45-57.

[52] Powers D. (n.d). About balconies. In eHow. Retrieved February 10, 2013, from

http://www.ehow.com/about_4709844_balconies.html.

[53] Ge H, McClung VR, Zhang S. Impact of balcony thermal bridges on the overall thermal performance of Multi-Unit Residential Buildings: A case study. Energy and Buildings. 2013.

[54] Papadakis G, Tsamis P, Kyritsis S. An experimental investigation of the effect of shading with plants for solar control of buildings. Energy and Buildings. 2001;33:831-6.

[55] Berry R, Livesley SJ, Aye L. Tree canopy shade impacts on solar irradiance received by building walls and their surface temperature. Building and Environment. 2013;69:91-100.

[56] Huang YJ, Akbari H, Taha H, Rosenfeld AH. The Potential of Vegetation in Reducing Summer Cooling Loads in Residential Buildings. Journal of Climate and Applied Meteorology. 1987;26:1103-16.

[57] Nikoofard S, Ugursal VI, Beausoleil-Morrison I. Effect of external shading on household energy requirement for heating and cooling in Canada. Energy and Buildings. 2011;43:1627-35.

[58] Akbari H, Kurn DM, Bretz SE, Hanford JW. Peak power and cooling energy savings of shade trees. Energy and Buildings. 1997;25:139-48.

[59] Simpson JR, McPherson EG. Potential of tree shade for reducing residential energy use in California. Journal of Arboriculture. 1996;22:10-18.

[60] Pandit R, Laband DN. Energy savings from tree shade. Ecological Economics. 2010;69:1324-9.

[61] Laband DN, Sophocleus JP. An Experimental Analysis of the Impact of Tree Shade on Electricity Consumption. Arboriculture \& Urban Forestry. 2009;35(4):197-202.

[62] Osmundson T. Roof Gardens: History, Design and Construction. New York: Norton; 1999.

[63] Ong BL. Green plot ratio: an ecological measure for architecture and urban planning. Landscape and Urban Planning. 2003;63:197-211.

[64] Tian Y, Jim CY. Factors influencing the spatial pattern of sky gardens in the compact city of Hong Kong. Landscape and Urban Planning. 2011;101:299-309.

[65] Hodgson MJ, Oleson B, Fountain M. Environmental acceptability in an environmental field study. in: Healthy Buildings/IAQ. 1997;1:195-200.

[66] Guieysse B, Hort C, Platel V, Munoz R, Ondarts M, Revah S. Biological treatment of indoor air for VOC removal: Potential and challenges. Biotechnology Advances. 2008;26:398-410.

[67] Wood RA. Improving the indoor environment for health, well-being and productivity. In: Greening cities: A new urban ecology. Australian Technology Park, Sydney, Australia. 2003.

[68] Papinchak HL, Holcomb EJ, Best TO, Decoteau DR. Effectiveness of Houseplants in Reducing the Indoor Air Pollutant Ozone. HortTechnology. 2009;19:286-90.

[69] US EPA. (2012). An Introduction to Indoor Air Quality (IAQ). In United States Environmental Protection Agency. Retrieved February 10, 2013, from http://www.epa.gov/iaq/ia-intro.html.

[70] ASHRAE Standard. (2010). Ventilation for acceptable indoor air quality. ANSI/ASHRAE Addendum q to ANSI/ASHRAE Standard 62.1-2007. Retrieved August 11, 2014, from http://www.ashrae.org. 
[71] Wolverton, B.C. 1984. The role of plants and microorganisms in assuring a future supply of clean air and water. Natl. Aeronautics Space Admin., Natl. Space Technol. Lab., Stennis Space Center, MS.

[72] Godish T, Guindon C. An assessment of botanical air purification as a formaldehyde mitigation measure under dynamic laboratory chamber conditions. Environmental Pollution. 1989;62:13-20.

[73] Fjeld T, Bonnevie C. The effect of plants and artificial day-light on the well-being and health of office workers, school children and health care personnel. Seminar report: Reducing health complaints at work Plants for people, Int. Hort. Exhib. Floriade. 2002.

[74] Knowles L, MacLean P, Rosato M, Stanley C, Volpe S, Yousif D. Living wall: a feasibility study for the SLC. Final Report, ERS 250, University of Waterloo; 2002.

[75] Tarran J, Torpy F, Burchett M. Use of living pot-plants to cleanse indoor air - Research review. 6th International Conference on Indoor Air Quality. 2007:249-56.

[76] Pennisi SV, van Iersel MW. Quantification of Carbon Assimilation of Plants in Simulated and In Situ Interiorscapes. HortScience. 2012;47:468-76.

[77] Fjeld T, Veiersted B, Sandvik L, Riise G, Levy F. The effect of indoor foliage plants on health and discomfort symptoms among office workers. Indoor and Built Environment. 1998;7:204-09.

[78] Taib N, Abdullah A. Study of Landscape Gardens: Expectations and Users' Perceptions of a High-Rise Office Building. Procedia - Social and Behavioral Sciences. 2012;50:633-42.

[79] Alexander C, Ishikawa S, Silverstein M. A pattern language. New York: Oxford University Press; 1977. [80] Lohr VI. The contribution of interior plants to relative humidity in an office, p. 117-119. In: Diane Relf (ed.). The Role of Horticulture in Human Well-being and Social Development. Portland: Timber Press; 1992. 